\title{
Variability of the Transferrin Receptor 2 Gene in AMD
}

\author{
Daniel Wysokinski, ${ }^{1}$ Janusz Blasiak, ${ }^{1}$ Mariola Dorecka, ${ }^{2}$ Marta Kowalska, ${ }^{3,4}$ \\ Jacek Robaszkiewicz, ${ }^{3}$ Elzbieta Pawlowska, ${ }^{5}$ Jerzy Szaflik, ${ }^{6}$ and Jacek Pawel Szaflik ${ }^{6}$ \\ ${ }^{1}$ Department of Molecular Genetics, University of Lodz, Pomorska 141/143, 90-236 Lodz, Poland \\ ${ }^{2}$ Department of Ophthalmology, Medical University of Silesia, Ceglana 35, 40-514 Katowice, Poland \\ ${ }^{3}$ Laser Centrum Okulistyczne, ul. Boya 4A/24, 00-621 Warsaw, Poland \\ ${ }^{4}$ Department of Ophthalmology, Medical University of Warsaw, ul. Lindleya 4, 02-005 Warsaw, Poland \\ ${ }^{5}$ Department of Developmental Dentistry, Medical University of Lodz, Pomorska 251, 92-216 Lodz, Poland \\ ${ }^{6}$ Department of Ophthalmology, Medical University of Warsaw and Samodzielny Publiczny Kliniczny Szpital Okulistyczny, \\ Sierakowskiego 13, 03-709 Warsaw, Poland
}

Correspondence should be addressed to Jacek Pawel Szaflik; szaflik@ophthalmology.pl

Received 24 October 2013; Accepted 17 December 2013; Published 6 February 2014

Academic Editor: Fabrizia Bamonti

Copyright (C) 2014 Daniel Wysokinski et al. This is an open access article distributed under the Creative Commons Attribution License, which permits unrestricted use, distribution, and reproduction in any medium, provided the original work is properly cited.

Oxidative stress is a major factor in the pathogenesis of age-related macular degeneration (AMD). Iron may catalyze the Fenton reaction resulting in overproduction of reactive oxygen species. Transferrin receptor 2 plays a critical role in iron homeostasis and variability in its gene may influence oxidative stress and AMD occurrence. To verify this hypothesis we assessed the association between polymorphisms of the TFR2 gene and AMD. A total of 493 AMD patients and 171 matched controls were genotyped for the two polymorphisms of the TFR2 gene: $c .1892 \mathrm{C}>\mathrm{T}$ (rs2075674) and c. $-258+123 \mathrm{~T}>\mathrm{C}$ (rs4434553). We also assessed the modulation of some AMD risk factors by these polymorphisms. The CC and TT genotypes of the c.1892C $>$ T were associated with AMD occurrence but the latter only in obese patients. The other polymorphism was not associated with AMD occurrence, but the CC genotype was correlated with an increasing AMD frequency in subjects with BMI $<26$. The TT genotype and the T allele of this polymorphism decreased AMD occurrence in subjects above 72 years, whereas the TC genotype and the $\mathrm{C}$ allele increased occurrence of AMD in this group. The c.1892C $>$ T and c. $-258+123 \mathrm{~T}>\mathrm{C}$ polymorphisms of the TRF2 gene may be associated with AMD occurrence, either directly or by modulation of risk factors.

\section{Introduction}

Age-related macular degeneration is the leading cause of irreversible vision loss among elderly in the developed world and accounts for about half of all newly registered blindness cases. At the advanced stage AMD develops to one of two clinically distinct forms-dry or wet [1]. The dry (atrophic) form of AMD occurs in about $90 \%$ of patients and its outcome is an accumulation of drusen in the central region of the macula, between the retinal pigment epithelium (RPE) layer and the Bruch's membrane. The wet (neovascular or exudative AMD) form of AMD occurs only in $10 \%$ of patients; however, it is the most common cause of irreversible vision loss in this disease. This form is characterized by choroidal neovascularization leading to leakages and bleeding into the retina [2]. Local inflammatory process develops and central disciform scar is formed. Photoreceptors and retinal pigment epithelium degenerate, leading to the loss of central vision [2].

Oxidative stress plays a major role in AMD pathophysiology [3]. The retina is exposed to oxidative stress from endogenous and exogenous sources, which may exceed its oxidative defense capacity, causing retinal cell death [4].

The presence of free iron ions may enhance the level of oxidative stress through the Fenton reaction, which requires hydrogen peroxide, produced in the cell in several physiological processes [5]. Post mortem studies showed a higher concentration of iron in RPE layer and Bruch's membrane in AMD subjects than in non-AMD individuals [6]. Similarly, in 
TABLE 1: Sequences of primers and restriction enzymes for genotyping of the c. $-258+123 \mathrm{~T}>\mathrm{C}$ and c.1892C $>\mathrm{T}$ polymorphisms of the TRF2 gene.

\begin{tabular}{|c|c|c|c|c|}
\hline \multirow{3}{*}{$\begin{array}{l}\text { Polymorphism } \\
\text { c. }-258+123 \mathrm{~T}>\mathrm{C} \\
\text { (rs4434553) }\end{array}$} & \multicolumn{4}{|c|}{ Sequences of primers } \\
\hline & \multicolumn{3}{|c|}{$\begin{array}{c}\text { F: 5' GATCACATGGGTTTCTACCTCTTT } \\
\text { R: 5' CTTAGGTCTCAGGGGAGCAG }\end{array}$} & $\mathrm{PCR}^{\mathrm{a}} 375 \mathrm{bp}$ \\
\hline & ASO & $\begin{array}{l}\text { R-A spec: } 5^{\prime} \text { GACC } \\
\text { R-G spec: } 5^{\prime} \text { GACC }\end{array}$ & $\begin{array}{l}\text { ГAGGAGCTGATGTTC } \\
\text { TAGGAGCTGATGTTT }\end{array}$ & $\mathrm{ASO}^{\mathrm{b}} 224 \mathrm{bp}$ \\
\hline & Sequences of primers & $\begin{array}{c}\text { Enzyme } \\
\text { (target allele) }\end{array}$ & Target sequence & Genotypes $^{c}$ \\
\hline $\begin{array}{l}\text { c. } 1892 \mathrm{C}>\mathrm{T} \\
(\mathrm{rs} 2075674)\end{array}$ & $\begin{array}{l}\text { F: } 5^{\prime} \text {-ACTCCCTGCCGTCGAGTTCT-3' } \\
\text { R: } 5^{\prime} \text {-ACTCCCAGAGACCAAGAGCG-3' }\end{array}$ & MspA1I (T) & $\begin{array}{l}5^{\prime} \ldots \mathrm{C}(\mathrm{A} / \mathrm{C}) \mathrm{G} \downarrow \mathrm{C}(\mathrm{G} / \mathrm{T}) \mathrm{G} \ldots .3^{\prime} \\
3^{\prime} \ldots \mathrm{G}(\mathrm{T} / \mathrm{G}) \mathrm{C} \uparrow \mathrm{G}(\mathrm{C} / \mathrm{A}) \mathrm{C} \ldots 3^{\prime}\end{array}$ & $\begin{array}{c}\text { CC } 381 \\
\text { CT } \\
381 / 198 / 193 \\
\text { TT } 198 / 193\end{array}$ \\
\hline
\end{tabular}

F: forward primer. R: reverse primer. ${ }^{a} \mathrm{PCR}$ product length using only flanking primers. ${ }^{\mathrm{b}} \mathrm{PCR}$ product length with ASO reverse primers. ${ }^{\mathrm{c}}$ Restriction products lengths (bp) for each genotype.

a case study of patient suffering from aceruloplasminemia, a disease resulting from a defect in the ceruloplasmin gene, an accumulation of iron in the macula was found and features of AMD developed [7].

Cells absorb most of iron through the cooperation of transferrin (Tf) and its receptors 1 and 2 (TfR and TfR2) [8]. An elevated expression of both TF and TFR2 genes was found to be associated with AMD [9]. TFR2 is also involved in nontransferrin bound-iron uptake and plays an important role in iron homeostasis regulation $[10,11]$. Moreover, a number of mutations in TFR2 were reported to influence iron homeostasis leading to iron overload disease-hemochromatosis type III [12]. The association of AMD occurrence and family history of this disease confirms the importance of the hereditary component of AMD [13]. It is thought that genotypeenvironment interaction plays an important role in AMD incidence [14]. Therefore, we hypothesize that variations in TRF2, an important gene of iron metabolism, may influence the extent of oxidative stress and play a role in AMD pathogenesis. In the present work we checked for the association between two polymorphisms of the TRF2 gene: c.1892C > T (rs2075674) and c. $-258+123 \mathrm{~T}>\mathrm{C}$ (rs4434553) and AMD as well as modulation of this association by some AMD risk factors.

\section{Materials and Methods}

2.1. Subjects. Six hundred two individuals were enrolled in this study: 493 AMD patients (311 in wet form of the disease and 182 in its dry form) and 171 controls. The control group comprised of age- and sex-matched individuals routinely examined with clinically excluded AMD and other retinal diseases. No one patient reported any genetic disease. Every patient was subjected to an ophthalmic examination, including best-corrected visual acuity, intraocular pressure, slit lamp examination, and fundus examination, performed with a slit lamp equipped with either noncontact or contact fundus lenses. Diagnosis of AMD was confirmed by optical coherence tomography (OCT) and, in some cases, by fluorescein angiography (FA) and indocyanine green angiography (ICG). OCT evaluated retinal thickness, the presence of RPE atrophy, drusen, or subretinal fluid and intraretinal edema; angiography assessed the anatomical status of the retinal vessels and the presence of choroidal neovascularization and leakage. The criteria for patients' selection were based on the clinical usefulness; dry form corresponded to AREDS category 2, 3, and 4 (geographic atrophy subtype) while wet form to AREDS category 4 (choroidal neovascularization or neovascularmaculopathy subtype) [15]. The OCT examinations were performed with Stratus OCT model 3000, software version 4.0 (Oberkochen). The FA and ICG examinations were completed with a Topcon TRC-50I IX fundus camera equipped with the digital Image Net image system, version 2.14 (Topcon). Structured questionnaire was used in order to obtain information from all patients regarding their lifestyle habits and family/personal history of AMD. Venous blood samples were obtained following the written consent from the patients and the Bioethics Committee of the Medical University of Warsaw, Poland.

2.2. DNA Isolation. Genomic DNA was obtained from peripheral blood samples with the use of AxyPrep Blood Genomic DNA Miniprep kit (Axygen Biosciences) with all the steps performed according to the manufacturer's protocol. Samples of DNA were frozen at $-20^{\circ} \mathrm{C}$ until use.

2.3. Genotype Determination. Genotyping of the c.1892C > T polymorphism was performed with restriction fragment length polymorphism polymerase chain reaction (RFLPPCR). The reaction tube contained genomic DNA, $250 \mathrm{nM}$ of each primer, $50 \mathrm{nM}$ dNTP mix, $1.5 \mathrm{mM} \mathrm{MgCl}_{2}$, and $1.25 \mathrm{U}$ Taq polymerase (Biotools) in PCR reaction buffer $(100 \mathrm{mM}$ Tris- $\mathrm{HCl}, \mathrm{pH} 8.3,500 \mathrm{mM} \mathrm{KCl}$, and $0.1 \%$ gelatin). The sequences of primers are shown in Table 2. Thermal cycling conditions were initial denaturation at $95^{\circ} \mathrm{C}$ for $5 \mathrm{~min}, 29$ cycles: denaturation at $95^{\circ} \mathrm{C}$ for $30 \mathrm{~s}$, annealing at $56^{\circ} \mathrm{C}$ for $30 \mathrm{~s}$, and elongation at $72^{\circ} \mathrm{C}$ for $1 \mathrm{~min}$. Amplified fragments were digested for $4 \mathrm{~h}$ with the restriction enzyme MspA1I (Fermentas) (Table 1) and the samples were separated on an $8 \%$ polyacrylamide gel (Figure 1 ). For the genotype determination of the polymorphic site (c. $-258+123 \mathrm{~T}>\mathrm{C}, \mathrm{rs} 4434553)$ in TFR2 the allele-specific oligonucleotide polymerase chain 


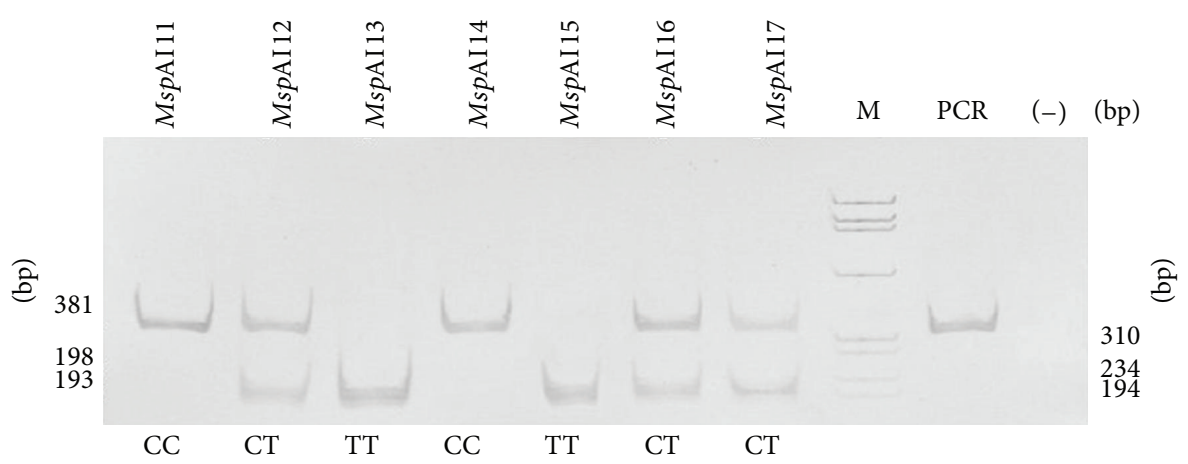

FIGURE 1: Representative picture of transferrin receptor polymorphism (c.1892C>T) analysis. The first lane (M) is DNA mass marker $\varphi$ X-174 DNA BsuRI. Digested PCR products were separated on a 10\% polyacrylamide gel and stained with ethidium bromide.

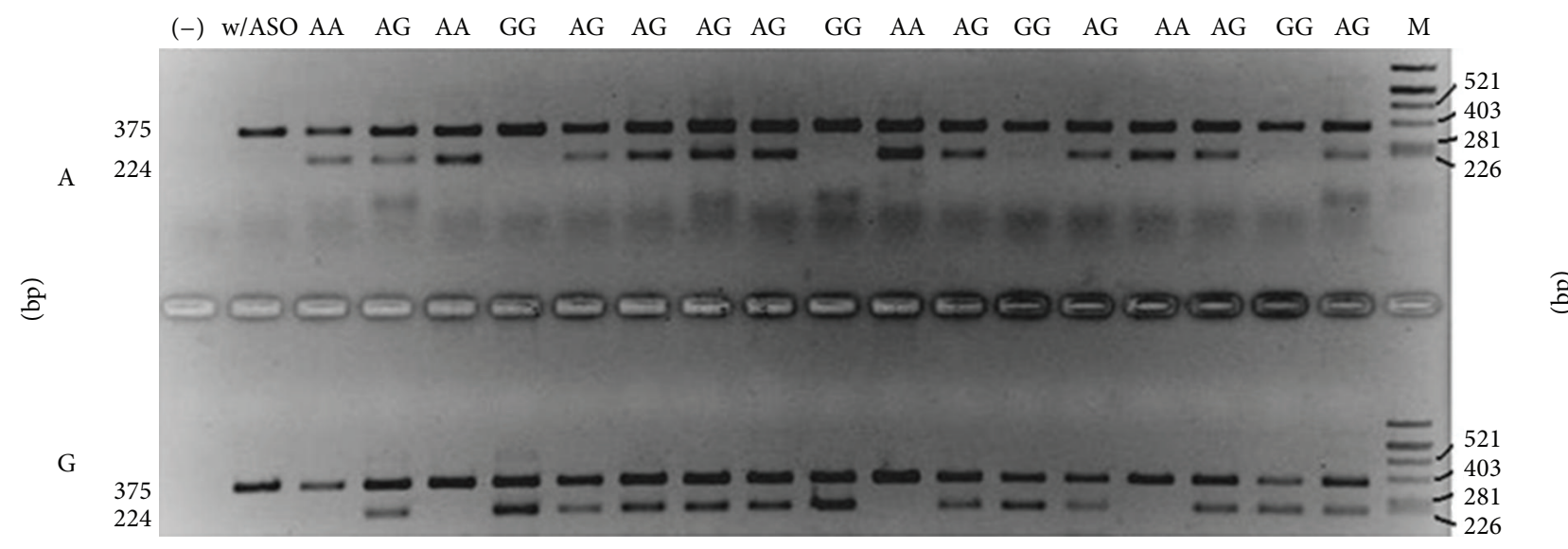

FIGURE 2: Representative picture of transferrin receptor polymorphism (c. $-258+123 \mathrm{~T}>\mathrm{C}$ ) analysis using allele-specific oligonucleotides PCR application. The first lane is negative control (no template), w/ASO is flanking (constitutive) primers only, and last lane (M) is DNA mass marker $\varphi \mathrm{X}-174$ DNA BsuRI. The upper row is the A allele-specific primer and lower row is the G allele-specific primer.

reaction (ASO-PCR) was used. Reaction tubes contained genomic DNA, polymerase buffer, $0.25 \mu \mathrm{M}$ of each primer (forward flanking, reverse flanking primer, and ASO-primer) (Sigma-Aldrich), $0.5 \mu \mathrm{M}$ dNTPs, $1.5 \mu \mathrm{M} \mathrm{MgCl}_{2}, 1 \mathrm{U} / \mu \mathrm{L}$ polymerase (BIOTOOLS B\&M Labs), and $\mathrm{H}_{2} \mathrm{O}$. Sequences of primers and lengths of DNA fragments are shown in Table 3. PCR was run on BIO-RAD C1000 Thermal Cycler (BIORAD Laboratories). Thermal cycling conditions were initial denaturation at $95^{\circ} \mathrm{C}$ for $3 \mathrm{~min}, 33$ cycles: denaturation at $95^{\circ} \mathrm{C}$ for $30 \mathrm{~s}$, annealing at $62^{\circ} \mathrm{C}$ for $30 \mathrm{~s}$, elongation at $72^{\circ} \mathrm{C}$ for $1 \mathrm{~min}$, and final extension at $72^{\circ} \mathrm{C}$ for $3 \mathrm{~min}$. The amplified DNA fragments were separated in $1.8 \%$ agarose gel (HR agarose, BIOTOOLS B\&M Labs), Tris-borate-EDTA buffer at $5 \mathrm{~V} / \mathrm{cm}$. The pBR322 DNA/AluI digest was used as a mass marker (Figure 2). The gels were stained with ethidium bromide and analyzed by the digital imaging system InGenius Bio Imaging (Syngene).

2.4. Serum Iron Assay. Venous blood samples were collected and centrifuged. Serum samples were portioned and stored frozen $\left(\hat{a} \breve{A} \breve{S} 20^{\circ} \mathrm{C}\right)$. Before use samples were centrifuged at $12000 \times \mathrm{g}$ for $15 \mathrm{~min}$. Serum iron level has been determined by QuantiChrom Iron Assay kit (Bioassay Systems) according
TABLE 2: The association of AMD with age, BMI, tobacco smoking, family history of AMD, and living environment.

\begin{tabular}{lcc}
\hline Factor & \multicolumn{2}{c}{ AMD } \\
& $\mathrm{OR}^{1)}(95 \% \mathrm{CI})$ & $P^{2)}$ \\
\hline Age $^{3)}$ & $\mathbf{1 . 0 2}(\mathbf{1 . 0 0}-\mathbf{1 . 0 4}) \uparrow$ & $<\mathbf{0 . 0 5}$ \\
BMI & $0.99(0.94-1.03)$ & - \\
Smoking (ever) & $0.88(0.6-1.28)$ & - \\
Family AMD & $\mathbf{8 . 8 8 ( 2 . 7 3 - 2 8 . 8 4 )} \uparrow$ & $<\mathbf{0 . 0 0 1}$ \\
Living enviromment & $0.69(0.4-1.19)$ & - \\
\hline${ }^{1)}{\text { Odds ratio with } 95 \% \text { confidence interval. }^{2)} \chi^{2} \text { test. }^{3)} \text { For }+1 \text { year. }}^{4)}$ Adjusted \\
to females. ${ }^{5)}$ Adjusted to rural. Data in boldface are statistically significant.
\end{tabular}

to the manufacturer's protocol. The absorbance was read at $450 \mathrm{~nm}$.

2.5. Data Analysis. Hardy-Weinberg equilibrium (HWE) was checked using the $\chi^{2}$ test for each group. The allelic frequencies were calculated by gene counting and genotypes were scored. The significance of the differences between distributions of genotypes and alleles was tested using the $\chi^{2}$ 
TABLE 3: Distribution of genotypes, frequency of alleles of the c.1892C > T polymorphism of the TFR2 gene, and odds ratios (OR) with $95 \%$ confidence intervals (95\% CI) in age-related macular degeneration (AMD) patients and controls.

\begin{tabular}{|c|c|c|c|c|c|c|}
\hline $\begin{array}{l}\text { Genotype/allele } \\
\text { c.1892C>T }\end{array}$ & $\begin{array}{c}\text { Control }(N=171) \\
N(\%)\end{array}$ & $\begin{array}{c}\operatorname{AMD}(N=493) \\
N(\%)\end{array}$ & $\mathrm{OR}^{1)}(95 \% \mathrm{CI})$ & $P^{2)}$ & $\mathrm{OR}^{3)}(95 \% \mathrm{CI})$ & $P^{2)}$ \\
\hline $\mathrm{CC}$ & $97(0.57)$ & $267(0.54)$ & $0.42(0.32-0.54) \downarrow$ & $<0.001$ & $0.86(0.6-1.23)$ & 0.411 \\
\hline $\mathrm{CT}$ & $54(0.32)$ & $183(0.37)$ & $1.28(0.88-1.85)$ & 0.196 & $1.35(0.93-1.97)$ & 0.118 \\
\hline TT & $20(0.12)$ & $43(0.09)$ & $0.72(0.41-1.27)$ & 0.288 & $0.71(0.4-1.26)$ & 0.246 \\
\hline $\mathrm{C}$ & $248(0.73)$ & $717(0.73)$ & $1.01(0.77-1.33)$ & 0.920 & $0.99(0.76-1.29)$ & 0.920 \\
\hline $\mathrm{T}$ & $94(0.27)$ & $269(0.27)$ & $0.99(0.75-1.3)$ & 0.920 & $1.01(0.78-1.33)$ & 0.920 \\
\hline
\end{tabular}

${ }^{1)}$ Crude odds ratio with $95 \%$ confidence interval; ${ }^{2)} \chi^{2}$ test; ${ }^{3)}$ odds ratio adjusted for age and sex.

Data in boldface are statistically significant.

analysis. Multiple logistic regression analysis was run to assess the association between the genotypes and alleles of the polymorphisms and AMD incidence. The genotypeassociated risk was expressed by crude odds ratio with $95 \%$ confidence intervals and the $P$ value. Odds ratios were then adjusted for possible interfering factors. To verify a potential gene-environment interaction, the patients and controls were stratified depending on age ( $<72$ years and $\geq 72$ years), sex, living environment (rural/urban), smoking status (never/former/current and never/moderate/heavy), and BMI $(<26 / 26-30 />30)$. Multiple logistic regression analyses were run to test the association of genotypes and environmental and social factors with AMD occurrence. To establish polymorphism influence on AMD form progression (wet/dry), the OR analysis was performed between both groups. The serum iron level was compared between AMD and control group using Mann-Whitney rank sum test. To assess the potential association between genotypes of polymorphisms and the iron level the 1-way ANOVA analysis was performed. Statistical analysis was performed using Statistica 9.0 package (Statsof).

\section{Results}

Initially we performed a genotype-independent analysis between those two groups of the environmental and social factors of confirmed or possible role in AMD. Those included age, BMI, smoking, family history of AMD (among 1st degree relatives), and environment of living (rural/urban) (Table 2). We found no association between AMD occurrence and BMI, smoking status, or the environment of living. However, an association was found for age and family AMD history. Next we analyzed the frequencies of the genotypes and alleles of polymorphisms in the TFR2 gene: c.1892C $>$ T and c.$258+123 \mathrm{~T}>\mathrm{C}$ in controls and AMD patients as well as in the group with the dry and wet forms of AMD. We found that the CC genotype of the c.1892C>T polymorphism was negatively correlated with the incidence of AMD (Table 3). We did not find any correlation between the c. $-258+123 \mathrm{~T}>\mathrm{C}$ polymorphism and AMD occurrence either for general AMD or for dry/wet form (data not shown). We then compared the frequencies of genotypes and alleles in the dry versus wet AMD groups to detect influence of the polymorphisms on AMD progression expressed as its transition from dry to wet form. We found that none of the genotypes/alleles of either polymorphism altered the risk of the progression of AMD (data not shown). In order to analyze the geneenvironment interaction, we stratified the groups depending on the potential risk factors. We found that the TT genotype of the c.1892C $>\mathrm{T}$ polymorphism had a protective effect against AMD occurrence for patients with $\mathrm{BMI}>30$ (Table 4), whereas the CC genotype of the c. $-258+123 \mathrm{~T}>\mathrm{C}$ polymorphism was associated with a decrease in AMD occurrence for individuals with BMI > 26 (Table 5). Moreover, the odds ratio analysis has shown that the TT genotype and the T allele reduced AMD occurrence in patients younger than 72 years, and the CT genotype and the C allele increased the risk. None of the genotypes/alleles altered AMD occurrence in patients aged 71 years and more (Table 6). Next, we compared the serum iron concentrations between AMD patients and controls. We did not observe any difference between these groups (Figure 3). We did not detect any association between the genotypes of both polymorphisms and iron concentration in serum.

\section{Discussion}

An exceptionally high metabolism rate in the retina together with the highest oxygen consumption and oxygen tension makes this organ especially prone to oxidative stress [16]. Moreover, the retina is constantly exposed to visible light, including high-energy blue light, which may generate ROS in photochemical reactions [17]. Photoreceptor outer segments are rich in polyunsaturated fatty acids (PUFA), which may be involved in the autoxidation cascade [18]. Similarly, retinal lipofuscin may undergo peroxidation and damage adjacent tissues [19]. Also catabolic processes in the retina generates ROS. Lipofuscin, and other photosensitizers, including melanin and rhodopsin, may absorb high-energy photons leading to photochemical reactions with generation of radical species [18]. Several lines of evidence suggest that an excess of iron, resulting from perturbations in iron homeostasis, may contribute to oxidative stress, which may play a role in numerous pathological conditions [20-22], including AMD [23]. Since transferrin-transferrin receptors iron uptake system seems to be of a special importance for iron balance in the organism, and numerous data indicate that deregulation of that system may be deleterious, it seems possible that it 
TABLE 4: Distribution of genotypes, frequency of alleles of the c.1892C > T polymorphism of the TFR2 gene, and odds ratios (OR) with 95\% confidence intervals $(95 \% \mathrm{CI})$ in age-related macular degeneration (AMD) patients and controls with respect to body mass index $(\mathrm{BMI})(<26$; $26-30 ;>30)$.

\begin{tabular}{|c|c|c|c|c|}
\hline \multirow{2}{*}{$\begin{array}{l}\text { Genotype/allele } \\
\text { c.1892C>T }\end{array}$} & \multicolumn{4}{|c|}{$\mathrm{BMI}<26$} \\
\hline & $\begin{array}{l}\text { Control (63) } \\
\text { Number (\%) }\end{array}$ & $\begin{array}{c}\text { AMD (153) } \\
\text { Number (\%) }\end{array}$ & $\mathrm{OR}^{1)}(95 \% \mathrm{CI})$ & $P^{2)}$ \\
\hline $\mathrm{CC}$ & $38(0.6)$ & $78(0.51)$ & $0.66(0.36-1.21)$ & 0.180 \\
\hline $\mathrm{CT}$ & $20(0.32)$ & $55(0.36)$ & $1.19(0.63-2.24)$ & 0.588 \\
\hline $\mathrm{TT}$ & $5(0.08)$ & $20(0.13)$ & $1.94(0.69-5.49)$ & 0.210 \\
\hline $\mathrm{C}$ & $96(0.76)$ & $211(0.69)$ & $0.7(0.45-1.1)$ & 0.121 \\
\hline $\mathrm{T}$ & $30(0.24)$ & $95(0.31)$ & $1.43(0.91-2.25)$ & 0.121 \\
\hline \multirow{2}{*}{$\begin{array}{l}\text { Genotype/allele } \\
\text { c.1892C>T }\end{array}$} & \multicolumn{4}{|c|}{ BMI 26-30 } \\
\hline & $\begin{array}{l}\text { Control (43) } \\
\text { Number (\%) }\end{array}$ & $\begin{array}{c}\text { AMD (146) } \\
\text { Number (\%) }\end{array}$ & $\mathrm{OR}^{1)}(95 \% \mathrm{CI})$ & $P^{2)}$ \\
\hline $\mathrm{CC}$ & $25(0.58)$ & $78(0.53)$ & $0.74(0.37-1.51)$ & 0.413 \\
\hline $\mathrm{CT}$ & $13(0.30)$ & $55(0.38)$ & $1.66(0.78-3.54)$ & 0.192 \\
\hline $\mathrm{TT}$ & $5(0.12)$ & $13(0.09)$ & $0.64(0.2-1.98)$ & 0.432 \\
\hline $\mathrm{C}$ & $63(0.73)$ & $211(0.72)$ & $0.93(0.54-1.59)$ & 0.778 \\
\hline $\mathrm{T}$ & $23(0.27)$ & $81(0.28)$ & $1.08(0.63-1.86)$ & 0.778 \\
\hline \multirow{2}{*}{$\begin{array}{l}\text { Genotype/allele } \\
\text { c.1892C>T }\end{array}$} & \multicolumn{4}{|c|}{$\mathrm{BMI}>30$} \\
\hline & $\begin{array}{l}\text { Control (39) } \\
\text { Number (\%) }\end{array}$ & $\begin{array}{c}\text { AMD (77) } \\
\text { Number (\%) }\end{array}$ & $\mathrm{OR}^{1)}(95 \% \mathrm{CI})$ & $P^{2)}$ \\
\hline $\mathrm{CC}$ & $22(0.56)$ & $42(0.55)$ & $0.85(0.38-1.87)$ & 0.683 \\
\hline $\mathrm{CT}$ & $10(0.26)$ & $32(0.42)$ & $2.32(0.96-5.58)$ & 0.061 \\
\hline TT & $7(0.18)$ & $3(0.04)$ & $0.19(0.04-0.78) \downarrow$ & 0.022 \\
\hline $\mathrm{C}$ & $54(0.69)$ & $116(0.75)$ & $1.26(0.7-2.29)$ & 0.441 \\
\hline $\mathrm{T}$ & $24(0.31)$ & $38(0.25)$ & $0.79(0.44-1.44)$ & 0.441 \\
\hline
\end{tabular}

${ }^{1)}$ Adjusted for age and sex; ${ }^{2)} \chi^{2}$; data in boldface are statistically significant.

may also play a role in AMD pathogenesis. Our previous data suggest that transferrin gene variation may contribute to AMD, and transferrin level may differ between AMD and controls [24]. Therefore, it may be expected that the gene encoding transferrin receptor 2 may also be associated with this condition. Disturbances in the TFR2 gene expression may result in cellular damage directly related to oxidative stress $[25,26]$.

We chose two polymorphisms in TFR2, which may have a phenotypic manifestation. The c.1892C $>\mathrm{T}$ polymorphism is a synonymous change p.Ala617. Using open-access SNP annotation tools we assessed that this change may be involved in splicing regulation-a $\mathrm{T}$ variant may create the site for exonic splicing repressor (hnRNP-H) binding [27]. The other polymorphism, positioned $5^{\prime}$-upstream, c. $-258+123 \mathrm{~T}>\mathrm{C}$, is located inside the binding site for the GATA-1 transcription factor [28], which is known to regulate TFR2 expression [29]. We found that in our group, despite age being an ex definitione key risk factor for AMD, also positive family history was independently associated with AMD occurrence, and this is consistent with numerous previous reports, suggesting a strong genetic basis of AMD. Unexpectedly, we found no correlation between AMD and smoking status, although we speculate that this association may fall beyond the sensitivity threshold of our experiment, mainly because of not enough number of smoking-positive responses in the questionnaire. Next, we performed an OR analysis to search for a direct association between genotypes and alleles of the polymorphisms and AMD occurrence. We found no association between c. $-258+123 \mathrm{~T}>\mathrm{C}$ and AMD occurrence. For the c.1892C > T polymorphism we found that the common variant CC may be associated with a lower frequency of AMD occurrence, although this association was significant in crude OR only, and becomes nonsignificant after adjusting for age and sex. Therefore, this association remains uncertain and requires further analysis. Moreover, the minor, T/T, variant of the c.1892C $>\mathrm{T}$ polymorphism may have protective role among individuals with BMI above 30 . We observed also a protective effect of the CC genotype of the c. $-258+123 \mathrm{~T}>\mathrm{C}$ polymorphism in the subgroup of low BMI value $(<26)$. Overweight and obesity are often reported to play a role in AMD pathogenesis [30]. We did not obtain results indicating the $\mathrm{BMI}$ as an independent risk factor for $\mathrm{AMD}$, but we detected a gene-BMI interplay as a potential risk predictor for AMD and such interactions have been reported elsewhere [31]. Another association was observed between the c.$258+123 \mathrm{~T}>\mathrm{C}$ polymorphism and age - the group aged below 72 years; the common TT genotype of this polymorphism might have a protective role against AMD occurrence, while the rare $\mathrm{CC}$ variant might enhance the occurrence of 
TABLE 5: Distribution of genotypes, frequency of alleles of the c. $-258+123 \mathrm{~T}>\mathrm{C}$ polymorphism of the TFR2 gene, and odds ratios (OR) with $95 \%$ confidence intervals (95\% CI) in age-related macular degeneration (AMD) and controls with respect to body mass index (BMI) (<26; $26-30 ;>30)$.

\begin{tabular}{|c|c|c|c|c|}
\hline \multirow{2}{*}{$\begin{array}{l}\text { Genotype/allele c. } \\
-258+123 \mathrm{~T}>\mathrm{C}\end{array}$} & \multicolumn{4}{|c|}{ BMI $<26$} \\
\hline & $\begin{array}{l}\text { Control (63) } \\
\text { Number (\%) }\end{array}$ & $\begin{array}{c}\text { AMD (153) } \\
\text { Number (\%) }\end{array}$ & $\mathrm{OR}^{1)}(95 \% \mathrm{CI})$ & $P^{2)}$ \\
\hline $\mathrm{TT}$ & $22(0.35)$ & $55(0.36)$ & $1.05(0.57-1.96)$ & 0.870 \\
\hline TC & $24(0.38)$ & $74(0.48)$ & $1.57(0.85-2.88)$ & 0.149 \\
\hline $\mathrm{CC}$ & $17(027)$ & $24(0.16)$ & $0.48(0.23-0.98) \downarrow$ & 0.044 \\
\hline $\mathrm{T}$ & $68(0.54)$ & $184(0.60)$ & $1.29(0.86-1.95)$ & 0.224 \\
\hline $\mathrm{C}$ & $58(0.46)$ & $122(0.40)$ & $0.77(0.51-1.17)$ & 0.224 \\
\hline \multirow{2}{*}{$\begin{array}{l}\text { Genotype/allele c. } \\
-258+123 \mathrm{~T}>\mathrm{C}\end{array}$} & \multicolumn{4}{|c|}{ BMI 26-30 } \\
\hline & $\begin{array}{l}\text { Control (43) } \\
\text { Number (\%) }\end{array}$ & $\begin{array}{c}\text { AMD (144) } \\
\text { Number (\%) }\end{array}$ & $\mathrm{OR}^{1)}(95 \% \mathrm{CI})$ & $P^{2)}$ \\
\hline TT & $14(0.33)$ & $50(0.35)$ & $1.11(0.53-2.33)$ & 0.790 \\
\hline TC & $19(0.44)$ & $63(0.44)$ & $1.03(0.51-2.09)$ & 0.937 \\
\hline $\mathrm{CC}$ & $10(0.23)$ & $31(0.22)$ & $0.84(0.36-1.9)$ & 0.685 \\
\hline $\mathrm{T}$ & $47(0.55)$ & $163(0.57)$ & $1.1(0.69-1.77)$ & 0.690 \\
\hline $\mathrm{C}$ & $39(0.45)$ & $125(0.43)$ & $0.91(0.57-1.46)$ & 0.690 \\
\hline \multirow{2}{*}{$\begin{array}{l}\text { Genotype/allele c. } \\
-258+123 \mathrm{~T}>\mathrm{C}\end{array}$} & \multicolumn{4}{|c|}{ BMI $>30$} \\
\hline & $\begin{array}{l}\text { Control (171) } \\
\text { Number (\%) }\end{array}$ & $\begin{array}{c}\text { AMD (77) } \\
\text { Number (\%) }\end{array}$ & $\mathrm{OR}^{1)}(95 \% \mathrm{CI})$ & $P^{2)}$ \\
\hline $\mathrm{TT}$ & $60(0.35)$ & $21(0.27)$ & $0.69(0.3-1.58)$ & 0.373 \\
\hline $\mathrm{TC}$ & $75(0.43)$ & $39(0.51)$ & $1.16(0.53-2.55)$ & 0.710 \\
\hline $\mathrm{CC}$ & $38(0.22)$ & $17(0.22)$ & $1.32(0.49-3.53)$ & 0.580 \\
\hline $\mathrm{T}$ & $193(0.56)$ & $81(0.53)$ & $0.78(0.45-1.35)$ & 0.374 \\
\hline $\mathrm{C}$ & $149(0.44)$ & $73(0.47)$ & $1.28(0.74-2.23)$ & 0.374 \\
\hline
\end{tabular}

${ }^{1)}$ Adjusted for age and sex; ${ }^{2)} \chi^{2}$ test; data in boldface are statistically significant.

TABLE 6: Distribution of genotypes, frequency of alleles of the c.258+123T>C polymorphism of the TFR2 gene, and odds ratios (OR) with $95 \%$ confidence intervals (95\% CI) in age-related macular degeneration (AMD) and controls in two age groups $(<72$ and $\geq 72)$.

\begin{tabular}{|c|c|c|c|c|c|c|c|c|}
\hline \multirow{4}{*}{$\begin{array}{l}\text { Genotype/allele } \\
\text { c. }-258+123 T>C\end{array}$} & \multicolumn{8}{|c|}{ Age } \\
\hline & & $<72$ & & \multirow{3}{*}{$P^{2)}$} & \multicolumn{4}{|c|}{$\geq 72$} \\
\hline & $\begin{array}{c}\text { Control } \\
(N=87)\end{array}$ & $\operatorname{AMD}(N=227)$ & $\mathrm{OR}^{1)}(95 \% \mathrm{CI})$ & & Control $(N=83)$ & $\operatorname{AMD}(N=247)$ & $\mathrm{OR}^{1)}(95 \% \mathrm{CI})$ & $P^{2)}$ \\
\hline & $N(\%)$ & $N(\%)$ & & & $N(\%)$ & $N(\%)$ & & \\
\hline TT & $38(0.44)$ & $76(0.33)$ & $0.33(0.15-0.73) \downarrow$ & 0.006 & $21(0.25)$ & $80(0.32)$ & $1.79(0.73-4.39)$ & 0.203 \\
\hline TC & $33(0.38)$ & $101(0.44)$ & $2.57(1.11-5.96) \uparrow$ & 0.028 & $40(0.48)$ & $123(0.50)$ & $0.94(0.43-2.09)$ & 0.887 \\
\hline $\mathrm{CC}$ & $16(0.18)$ & $50(0.22)$ & $1.41(0.55-3.64)$ & - & $22(0.27)$ & $44(0.18)$ & $0.54(0.21-1.41)$ & 0.209 \\
\hline $\mathbf{T}$ & $109(0.63)$ & $253(0.56)$ & $0.56(0.33-0.95) \downarrow$ & 0.031 & $82(0.49)$ & $283(0.57)$ & $1.57(0.89-2.78)$ & 0.123 \\
\hline $\mathrm{C}$ & $65(0.37)$ & $201(0.44)$ & $1.79(1.05-3.03) \uparrow$ & 0.031 & $84(0.51)$ & $211(0.43)$ & $0.64(0.36-1.13)$ & 0.123 \\
\hline
\end{tabular}

the disease. These results may suggest that at a young age the influence of genetic factors may be more prominent in AMD pathogenesis, whereas later the age-related processes may play a central role. Lastly, we found no significant difference between serum iron levels in AMD and control group, so we concluded that the process of AMD pathogenesis and possible disturbances in iron homeostasis may not cause changes in serum iron level. However it is also possible that such change may be specific for the eye. This aspect seems especially interesting and further searching for iron level differences between particular organs/systems would bring significant progress in defining the role of iron in AMD.

\section{Conclusions}

In this study we presented the data suggesting that variants of the TFR2 gene may play a role in the modulation of AMD risk. We reported the interaction effect between polymorphisms 


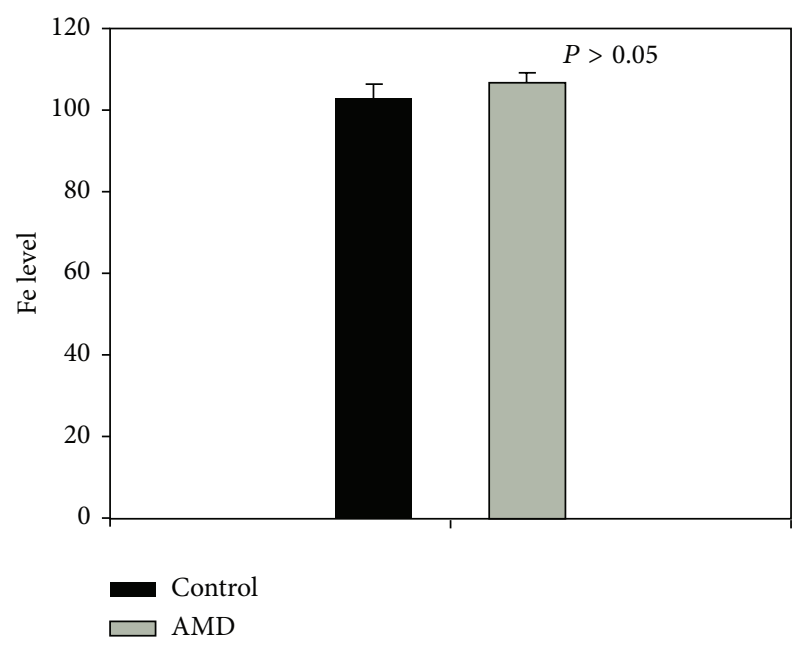

FIGURE 3: Mean concentration of serum iron level $[\mu \mathrm{g} / \mathrm{dL}]$ in control and AMD group assessed colorimetrically. Control group is black bar and AMD patients is gray bar. One hundred and seventy one persons were analyzed for the control, and 662 were analyzed for AMD.

of the TFR2 gene with BMI and age. These results suggest an important role of iron homeostasis in AMD pathogenesis.

\section{Abbreviations}

AMD: $\quad$ Age-related macular degeneration

RPE: $\quad$ Retinal pigment epithelium

OCT: Optical coherence tomography

FA: $\quad$ Fluorescein angiography

ICG: Indocyanine green angiography

AREDS: Age-Related Eye Disease Study

RFLP-PCR: Restriction fragment length polymorphism polymerase chain reaction

ASO-PCR: Allele-specific oligonucleotide polymerase chain reaction

HWE: Hardy-Weinberg equilibrium

OR: $\quad$ Odds ratio

BMI: $\quad$ Body mass index

UV: Ultraviolet

ROS: $\quad$ Reactive oxygen species

PUFA: $\quad$ Polyunsaturated fatty acids

SD: $\quad$ Standard deviation.

\section{Conflict of Interests}

The authors declare that there is no conflict of interests regarding the publication of this paper.

\section{Acknowledgment}

This work was supported by Grant N N402 248336 from the Polish Ministry of Science and Higher Education.

\section{References}

[1] H. K. Hamdi and C. Kenney, "Age-related macular degeneration: a new viewpoint," Frontiers in Bioscience, vol. 8, pp. e305e314, 2003.

[2] S. B. Bressler, "Introduction: understanding the role of angiogenesis and antiangiogenic agents in age-related macular degeneration," Ophthalmology, vol. 116, no. 10, supplement, pp. S1-S7, 2009.

[3] S. Khandhadia and A. Lotery, "Oxidation and age-related macular degeneration: insights from molecular biology," Expert Reviews in Molecular Medicine, vol. 12, article e34, 2010.

[4] S. G. Jarrett and M. E. Boulton, "Consequences of oxidative stress in age-related macular degeneration," Molecular Aspects of Medicine, vol. 33, no. 4, pp. 399-417, 2012.

[5] K. Jomova and M. Valko, "Advances in metal-induced oxidative stress and human disease," Toxicology, vol. 283, no. 2-3, pp. 6587, 2011.

[6] P. Hahn, A. H. Milam, and J. L. Dunaief, "Maculas affected by age-related macular degeneration contain increased chelatable iron in the retinal pigment epithelium and Bruch's membrane," Archives of Ophthalmology, vol. 121, no. 8, pp. 1099-1105, 2003.

[7] J. L. Dunaief, C. Richa, E. P. Franks et al., "Macular degeneration in a patient with aceruloplasminemia, a disease associated with retinal iron overload," Ophthalmology, vol. 112, no. 6, pp. 10621065, 2005.

[8] A. C. G. Chua, R. M. Graham, D. Trinder, and J. K. Olynyk, "The regulation of cellular iron metabolism," Critical Reviews in Clinical Laboratory Sciences, vol. 44, no. 5-6, pp. 413-459, 2007.

[9] I. Chowers, R. Wong, T. Dentchev et al., "The iron carrier transferrin is upregulated in retinas from patients with age-related macular degeneration," Investigative Ophthalmology \& Visual Science, vol. 47, no. 5, pp. 2135-2140, 2006.

[10] R. M. Graham, G. M. Reutens, C. E. Herbison et al., "Transferrin receptor 2 mediates uptake of transferrin-bound and nontransferrin-bound iron," Journal of Hepatology, vol. 48, no. 2, pp. 327-334, 2008.

[11] Y. Deugnier, "The iron driven pathway of hepcidin synthesis," Gastroentérologie Clinique et Biologique, vol. 34, no. 6-7, pp. 351354, 2010.

[12] J. Chen and C. A. Enns, "Hereditary hemochromatosis and transferrin receptor 2," Biochimica et Biophysica Acta, vol. 1820, no. 3, pp. 256-263, 2012.

[13] C. J. Hammond, A. R. Webster, H. Snieder, A. C. Bird, C. E. Gilbert, and T. D. Spector, "Genetic influence on early agerelated maculopathy: a twin study," Ophthalmology, vol. 109, no. 4, pp. 730-736, 2002.

[14] Y. Chen, M. Bedell, and K. Zhang, "Age-related macular degeneration: genetic and environmental factors of disease," Molecular Interventions, vol. 10, no. 5, pp. 271-281, 2010.

[15] F. L. Ferris, M. D. Davis, T. E. Clemons et al., "A simplified severity scale for age-related macular degeneration: AREDS report no. 18," Archives of Ophthalmology, vol. 123, no. 11, pp. 1570-1574, 2005.

[16] F. Roth, A. Bindewald, and F. G. Holz, "Keypathophysiologic pathways in age-related macular disease," Graefe's Archive for Clinical and Experimental Ophthalmology, vol. 242, no. 8, pp. 710-716, 2004.

[17] D. H. Sliney, "How light reaches the eye and its components," International Journal of Toxicology, vol. 21, no. 6, pp. 501-509, 2002. 
[18] S. Beatty, H. Koh, M. Phil, D. Henson, and M. Boulton, “The role of oxidative stress in the pathogenesis of age-related macular degeneration," Survey of Ophthalmology, vol. 45, no. 2, pp. 115134, 2000.

[19] A. E. Dontsov, N. L. Sakina, A. M. Golubkov, and M. A. Ostrovsky, "Light-induced release of A2E photooxidation toxic products from lipofuscin granules of human retinal pigment epithelium," Doklady Biochemistry and Biophysics, vol. 425, no. 1, pp. 98-101, 2009.

[20] G. F. de Souza, M. C. Barbosa, T. E. Santos et al., "Increased parameters of oxidative stress and its relation to transfusion iron overload in patients with myelodysplastic syndromes," Journal of Clinical Pathology, vol. 66, no. 11, pp. 996-998, 2013.

[21] W. Lu, M. Zhao, S. Rajbhandary et al., "Free iron catalyzes oxidative damage to hematopoietic cells/mesenchymal stem cells in vitro and suppresses hematopoiesis in iron overload patients," European Journal of Haematology, vol. 91, no. 3, pp. 249-261, 2013.

[22] D. J. Messner, B. H. Rhieu, and K. V. Kowdley, "Iron overload causes oxidative stress and impaired insulin signaling in AML12 hepatocytes," Digestive Diseases and Sciences, vol. 58, no. 7, pp. 1899-1908, 2013.

[23] J. Blasiak, J. Szaflik, and J. P. Szaflik, "Implications of altered iron homeostasis for age-related macular degeneration," Frontiers in Bioscience, vol. 16, no. 4, pp. 1551-1559, 2011.

[24] D. Wysokinski, K. Danisz, J. Blasiak et al., "An association of transferrin gene polymorphism and serum transferrin levels with age-related macular degeneration," Experimental Eye Research, vol. 106, pp. 14-23, 2013.

[25] E. Bardou-Jacquet, S. Cunat, M. P. Beaumont-Epinette et al., "Variable age of onset and clinical severity in transferrin receptor 2 related haemochromatosis: novel observations," British Journal of Haematology, vol. 162, no. 2, pp. 278-281, 2013.

[26] R. D. Delima, A. C. Chua, J. E. Tirnitz-Parker et al., "Disruption of hemochromatosis protein and transferrin receptor 2 causes iron-induced liver injury in mice," Hepatology, vol. 56, no. 2, pp. 585-593, 2012.

[27] A. Goren, O. Ram, M. Amit et al., "Comparative analysis identifies exonic splicing regulatory sequences-the complex definition of enhancers and silencers," Molecular Cell, vol. 22, no. 6, pp. 769-781, 2006.

[28] P. H. Lee and H. Shatkay, "An integrative scoring system for ranking SNPs by their potential deleterious effects," Bioinformatics, vol. 25, no. 8, pp. 1048-1055, 2009.

[29] H. Kawabata, R. E. Fleming, D. Gui et al., "Expression of hepcidin is down-regulated in TfR2 mutant mice manifesting a phenotype of hereditary hemochromatosis," Blood, vol. 105, no. 1, pp. 376-381, 2005.

[30] R. Karadag, Z. Arslanyilmaz, B. Aydin, and I. F. Hepsen, "Effects of body mass index on intraocular pressure and ocular pulse amplitude," International Journal of Ophthalmology, vol. 5, no. 5, pp. 605-608, 2012.

[31] C. J. Chiu, Y. P. Conley, M. B. Gorin et al., "Associations between genetic polymorphisms of insulin-like growth factor axis genes and risk for age-related macular degeneration," Investigative Ophthalmology \& Visual Science, vol. 52, no. 12, pp. 9099-9107, 2011. 


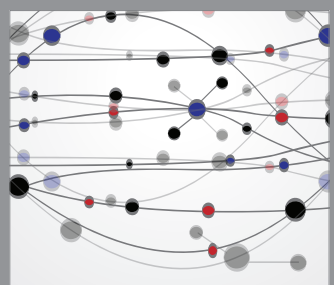

The Scientific World Journal
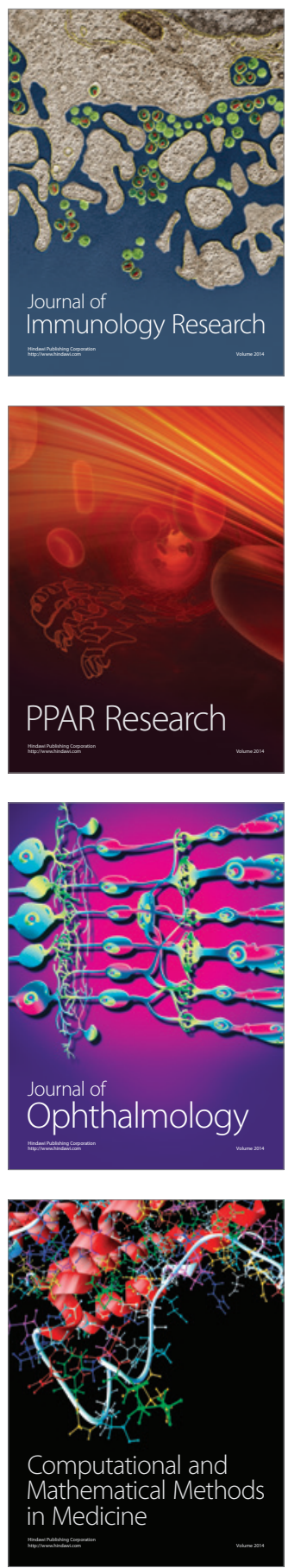

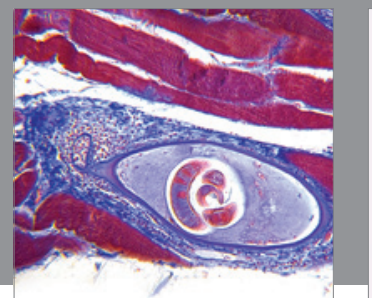

Gastroenterology

Research and Practice
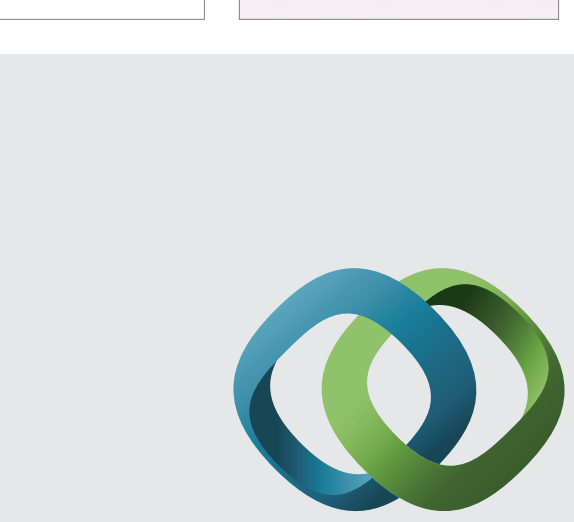

\section{Hindawi}

Submit your manuscripts at

http://www.hindawi.com
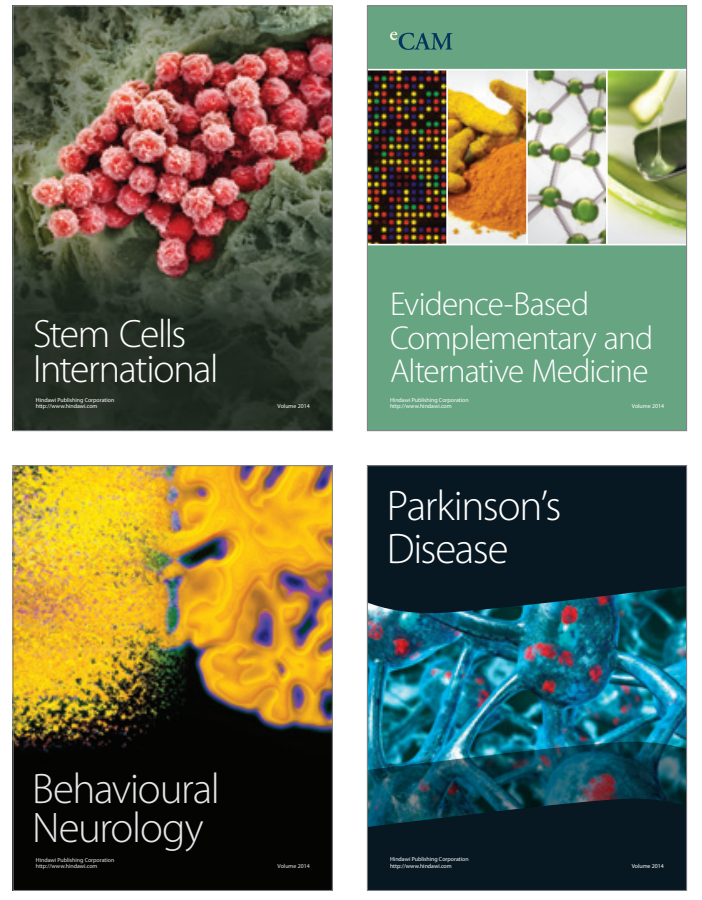
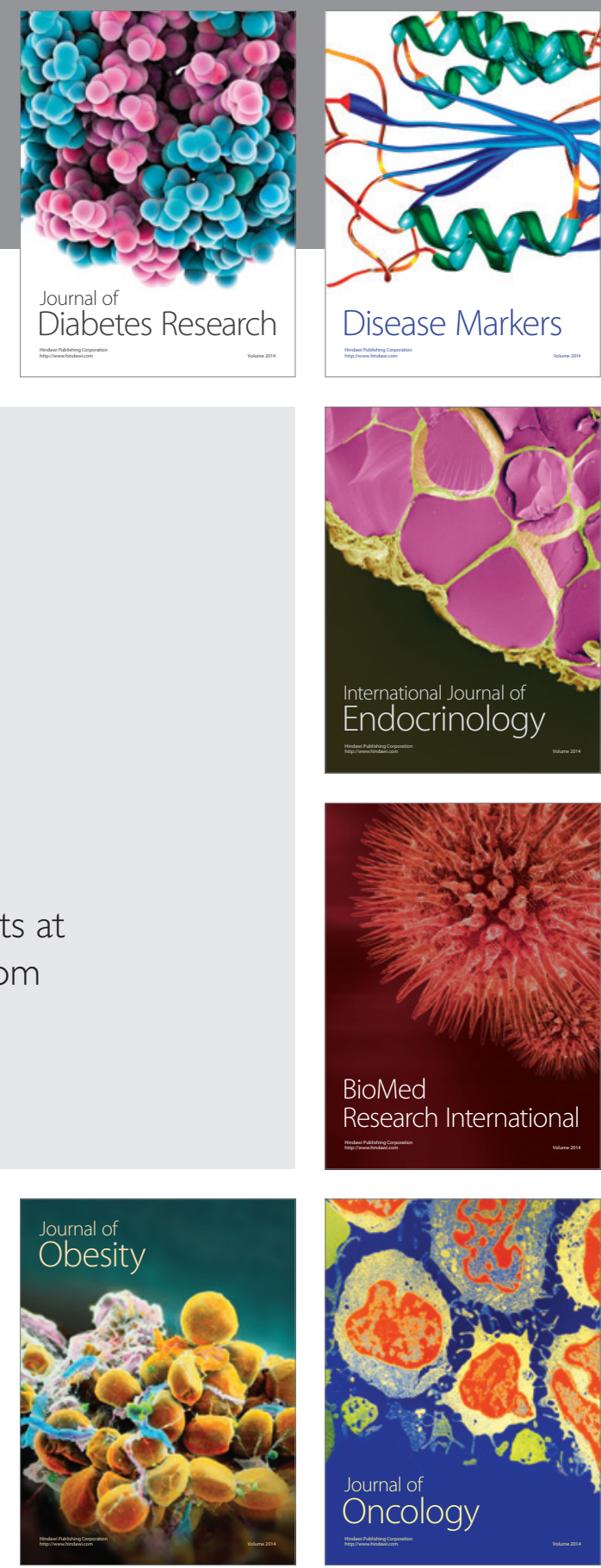

Disease Markers
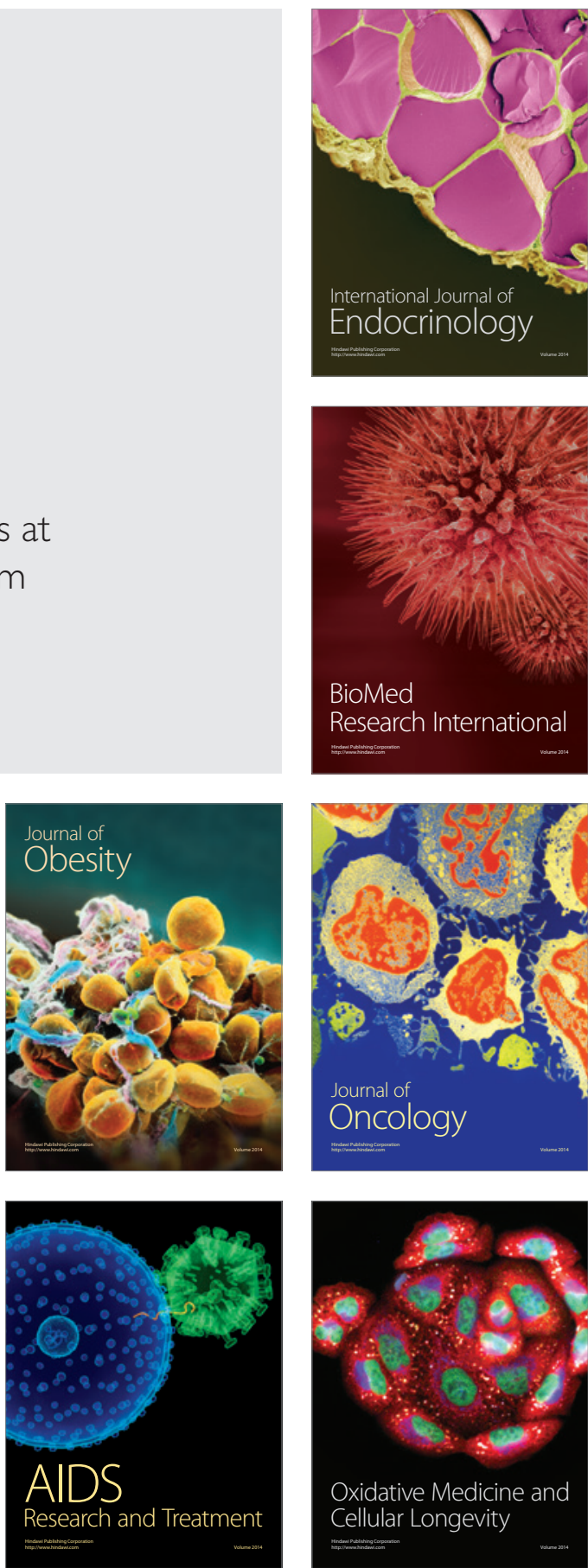